\title{
Environmental performance of crop cultivation at different sites and nitrogen rates in Sweden
}

\author{
Kajsa Henryson (1) P Per-Anders Hansson • Thomas Kätterer • Pernilla Tidåker • \\ Cecilia Sundberg
}

Received: 14 November 2018/Accepted: 29 April 2019/Published online: 8 May 2019

(C) The Author(s) 2019

\begin{abstract}
Nitrogen (N) fertilisation has positive and negative effects on the environmental impact of crop cultivation. The mechanisms governing these effects are highly site-dependent, a factor often ignored in assessments of the environmental impact of crop cultivation. By assessing outputs of crop rotations using a life cycle approach, this study explored how greenhouse gas emissions and marine eutrophication caused by crop cultivation (including upstream processes such as production of farm inputs) depend on fertiliser rate and the site at which the cultivation occurs. Cereal unit (CU) was used as the functional
\end{abstract}

Electronic supplementary material The online version of this article (https://doi.org/10.1007/s10705-019-09997-w) contains supplementary material, which is available to authorized users.

K. Henryson $(\bowtie)$ · P.-A. Hansson · P. Tidåker ·

C. Sundberg

Department of Energy and Technology, Swedish

University of Agricultural Sciences (SLU),

P.O. Box 7032, 75007 Uppsala, Sweden

e-mail: kajsa.henryson@slu.se

T. Kätterer

Department of Ecology, Swedish University of

Agricultural Sciences (SLU), P.O. Box 7044,

75007 Uppsala, Sweden

C. Sundberg

Department of Sustainable Development, Environmental

Science and Engineering, KTH Royal Institute of

Technology, Teknikringen 10B, 10044 Stockholm,

Sweden unit. The calculations were based on data from multisite long-term field experiments in Sweden and sitedependent data and models for non-measured processes. Cultivation at three $\mathrm{N}$ levels was evaluated, where the highest $\mathrm{N}$ rate was close to current average practices and the lowest level corresponded to onethird of that. Site characteristics had a stronger influence on both greenhouse gas emissions and marine eutrophication (variations of up to $330 \%$ and $490 \%$, respectively, within $\mathrm{N}$ levels) than $\mathrm{N}$ level (variations of up to $74 \%$ and $59 \%$, respectively, within sites). Main sources of variation in greenhouse gas emissions were soil nitrous oxide emissions (58-810 g $\mathrm{CO}_{2 \mathrm{eq}} \mathrm{CU}^{-1}$ ) and soil organic carbon changes (14-720 $\mathrm{g} \mathrm{CO}_{2 \mathrm{eq}} \mathrm{CU}^{-1}$ ), while variations in marine eutrophication were mainly explained by field-level waterborne $\mathrm{N}$ losses (0.9-8.2 $\mathrm{g} \mathrm{N}_{\mathrm{eq}} \mathrm{CU}^{-1}$ ). The large variation between sites highlights the importance of considering site characteristics when assessing the environmental impact of crop cultivation and evaluating the environmental consequences of crop management practices.

Keywords Environmental impact - Life cycle assessment - Eutrophication - Climate impact . Greenhouse gas emissions · Site-dependent 


\section{Introduction}

The introduction of mineral nitrogen $(\mathrm{N})$ fertilisers has enabled yield increases and has been a crucial factor for increasing global food security during the past century (Sutton et al. 2013). Increasing crop yields may also have several positive effects on the environment, such as increasing resource use efficiency, avoiding land use change and increasing input of crop residues available for soil carbon sequestration, but may require increased inputs of e.g. water and pesticides (Snyder et al. 2009; Tilman et al. 2002). Furthermore, $\mathrm{N}$ fertiliser use itself causes negative environmental impacts through fossil fuel use and losses of reactive $\mathrm{N}$ both during the production phase and after field application. It is therefore possible that there are trade-offs between several environmental objectives. Due to its multifaceted effects on agroecosystems, $\mathrm{N}$ fertiliser rate in relation to yield often emerges as one of the most influential variables for the magnitude of environmental impact of cropping systems (Van Stappen et al. 2017; Aoun et al. 2014; Charles et al. 2006). However, the relationship between $\mathrm{N}$ fertiliser rate and environmental impacts is complex, since both yield and field emissions of reactive $\mathrm{N}$ exhibit non-linear responses to increased $\mathrm{N}$ fertiliser rate (Delin and Stenberg 2014). Since both yield and emissions are also affected by local cultivation conditions such as climate and soil characteristics (Delin et al. 2005; Rochette et al. 2018), it is possible that the environmental impact of cultivation under different fertiliser rates will depend on the site. In that context, multi-site long-term field experiments are a valuable source of data.

Nitrogen fertiliser use is closely related to both greenhouse gas (GHG) emissions and nutrient losses to watersheds, which have been identified as key areas for actions to decrease the environmental impact of agriculture in the EU (European Commission 2017). Previous studies have shown that decreasing fertiliser input can reduce GHG emissions per unit produced (e.g. Ashworth et al. 2015; Williams et al. 2010; Brentrup et al. 2004; Goglio et al. 2012). However, since $\mathrm{N}$ fertilisers promote higher yields, this outcome may change if soil organic carbon (SOC) changes are included, which are also affected by site conditions (García-Ruiz et al. 2019). Another potential source of spatial variability in estimated GHG emissions is soil nitrous oxide $\left(\mathrm{N}_{2} \mathrm{O}\right)$ emissions, which are highly dependent on site conditions (Goglio et al. 2018). Site can thus influence estimated GHG emissions even though the impact itself is site-independent. Unlike climate impact, eutrophication is a site-dependent impact that mainly occurs due to regional emissions (Potting and Hauschild 2006). Eutrophication is a particularly urgent environmental issue for Sweden, which is surrounded by the world's largest anthropogenic hypoxic zone, the Baltic Sea (Diaz and Rosenberg 2008), where agriculture is one of the main contributors to this issue (Licker et al. 2010). The sitedependent nature of the eutrophication cause-effect chain means that it is necessary to consider where emissions occur in order to make meaningful assessments of eutrophication impact, especially when comparing products produced at different sites (Page et al. 2014).

A system perspective is necessary to account for the environmental impacts of different substance flows occurring during the process of producing crops. A commonly used tool for determining the environmental impact of a product is life cycle assessment (LCA), which is frequently used for agricultural products (Notarnicola et al. 2017). In LCA, emissions and resource use during the whole or part of the life cycle of a product or process are compiled and related to environmental impacts (ISO 2006). This approach enables identification of possible trade-offs between products or production process alternatives, and thereby reveals potential burden shifts between impact categories or life-cycle stages. LCA of cropping systems is typically performed for either a site representing average conditions or for one or a few specific sites, due to lack of data. Different methodologies and degrees of spatial specificity limit intercomparability (Bessou et al. 2013), and it is often unclear whether differences in results between studies can be attributed to spatial or methodological variations. The aim of this study was therefore to evaluate cradle-to-farm gate GHG emissions and marine eutrophication of crop cultivation at different $\mathrm{N}$ fertiliser levels and different field sites in Sweden, and to use the results to analyse the influence of these two factors on estimated environmental impact. Data from multi-site long-term field trials were used, together with site-dependent data and models for non-measured processes. 


\section{Methods}

\section{Experimental sites and set-up}

The assessment was based on data from nine sites in the Swedish Soil Fertility Trials (described by Carlgren and Mattsson 2001); four in southern (S1-S4) and five in central Sweden (C1-C5) (Fig. 1). These sites represent varying cultivation conditions in terms of soil characteristics and microclimate (Carlgren and Mattsson 2001). Selected site characteristics are shown in Table SM1 in Supplementary Material. The trials have been ongoing since the 1950s and 1960s in southern and central Sweden, respectively. The crop rotations included in the present study consisted of a four-year rotation in the southern region (Table 1), with two replicates at each site. The crop rotations included were exclusively given mineral fertilisers, and all crop residues were left in the field and incorporated into the soil. Three $\mathrm{N}$ levels were considered in the analysis: low, medium and high.

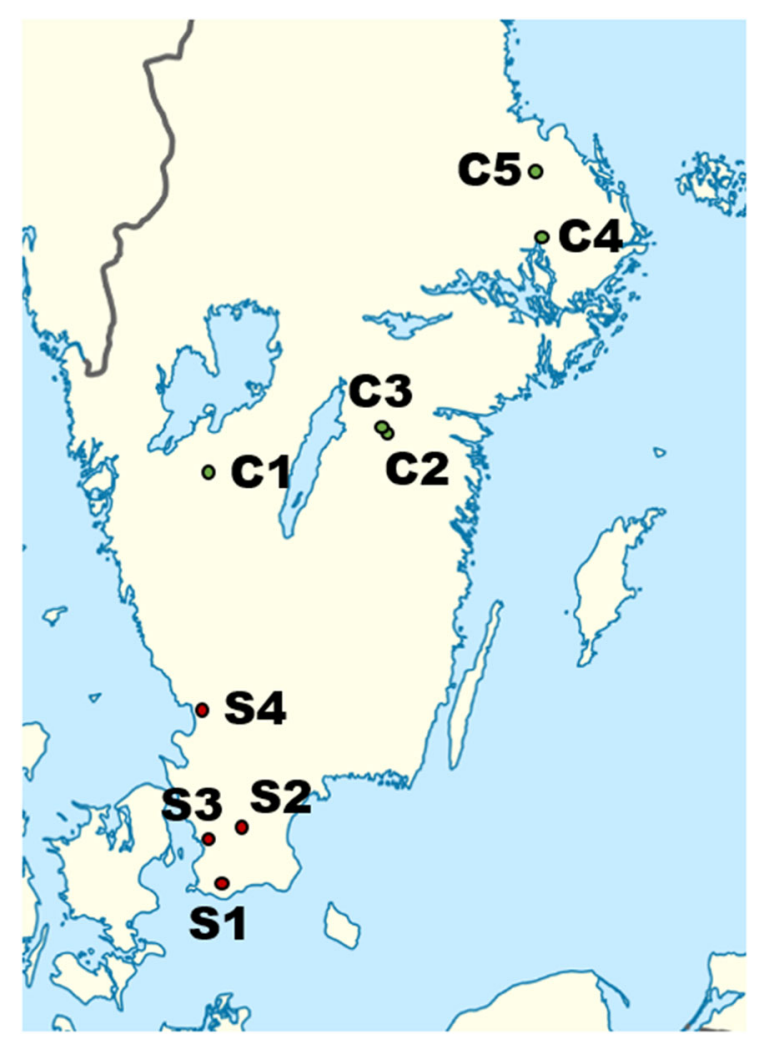

Fig. 1 Map showing location of experimental sites in southern Sweden (sites S1-S4) and central Sweden (sites C1-C5)
Fields receiving no $\mathrm{N}$ were not included in the analysis, since this does not reflect realistic agricultural practices, but are included in Fig. 2 to show the whole yield response curve. Average annual $\mathrm{N}$ fertiliser rates were higher at the southern sites than at the central sites (Table 1), but the high $\mathrm{N}$ level was close to current average cereal $\mathrm{N}$ fertilisation rates in each study region. Applied amounts of phosphorus (P) and potassium $(\mathrm{K})$ fertilisers were chosen to replace annual removal, but the $\mathrm{P}$ and $\mathrm{K}$ rates were also similar to current average practice in the two regions (Statistics Sweden 2016). A full list of fertiliser amounts is provided in Tables SM3-SM5. Hereafter, we use the term 'treatment' to refer to each combination of site and $\mathrm{N}$ level $(9 \times 3=27$ treatments).

Goal, scope, functional unit, system boundaries and assumptions

Life cycle assessment was used to assess the GHG emissions and marine eutrophication impact over the whole crop rotation, under three different $\mathrm{N}$ fertiliser levels, at the nine sites in southern and central Sweden. The system boundaries were set at cradle-to-farm gate, which included emissions from:

- Inputs (fertiliser and pesticide production)

- Field operations (fuel consumption, production and maintenance of machinery)

- Soil emissions (waterborne $\mathrm{N}$ and $\mathrm{P}$ compounds and airborne $\mathrm{N}_{2} \mathrm{O}$, ammonia $\left(\mathrm{NH}_{3}\right)$ and $\left.\mathrm{NO}_{\mathrm{x}}\right)$

- Crop drying

- SOC changes.

In LCA, a functional unit is needed to relate inputs and outputs to a common unit. The functional unit is a quantified description of the product system functions (ISO 2006), and should be chosen with respect to the goals of the study (Caffrey and Veal 2013). Dry or fresh matter mass of harvested crop, together with area occupied by the crop, are the most common functional units used for agricultural LCAs (Notarnicola et al. 2017). However, mass is not a fair representation of the crop function when different crop types are present, and therefore cereal unit (CU) was chosen as the functional unit in this study instead. Cereal unit was first introduced to LCAs by Brankatschk and Finkbeiner (2014), as a basis for co-product allocation between grain and straw (ibid.) or between the crops in 
Table 1 Crop rotations and fertiliser rates in the southern and central cropping systems

\begin{tabular}{|c|c|c|}
\hline & $\begin{array}{l}\text { Southern sites } \\
\text { (S1-S4) }\end{array}$ & $\begin{array}{l}\text { Central sites } \\
\text { (C1-C5) }\end{array}$ \\
\hline \multirow[t]{6}{*}{ Crop rotation } & Spring barley ${ }^{\mathrm{a}}$ & Spring barley ${ }^{\mathrm{a}}$ \\
\hline & Spring oilseed rape & Oats $^{c}$ \\
\hline & Winter wheat $^{\mathrm{d}}$ & Spring oilseed rape ${ }^{\mathrm{b}}$ \\
\hline & Sugar beet $\mathrm{e}^{\mathrm{e}}$ & Winter wheat $^{\mathrm{d}}$ \\
\hline & & Oats $^{c}$ \\
\hline & & Winter wheat $^{\mathrm{d}}$ \\
\hline Average fertiliser rate at low $\mathrm{N}$ level & 50 & 40 \\
\hline Average fertiliser rate at medium $\mathrm{N}$ level & 100 & 80 \\
\hline Average fertiliser rate at high $\mathrm{N}$ level & 150 & 120 \\
\hline
\end{tabular}

8000
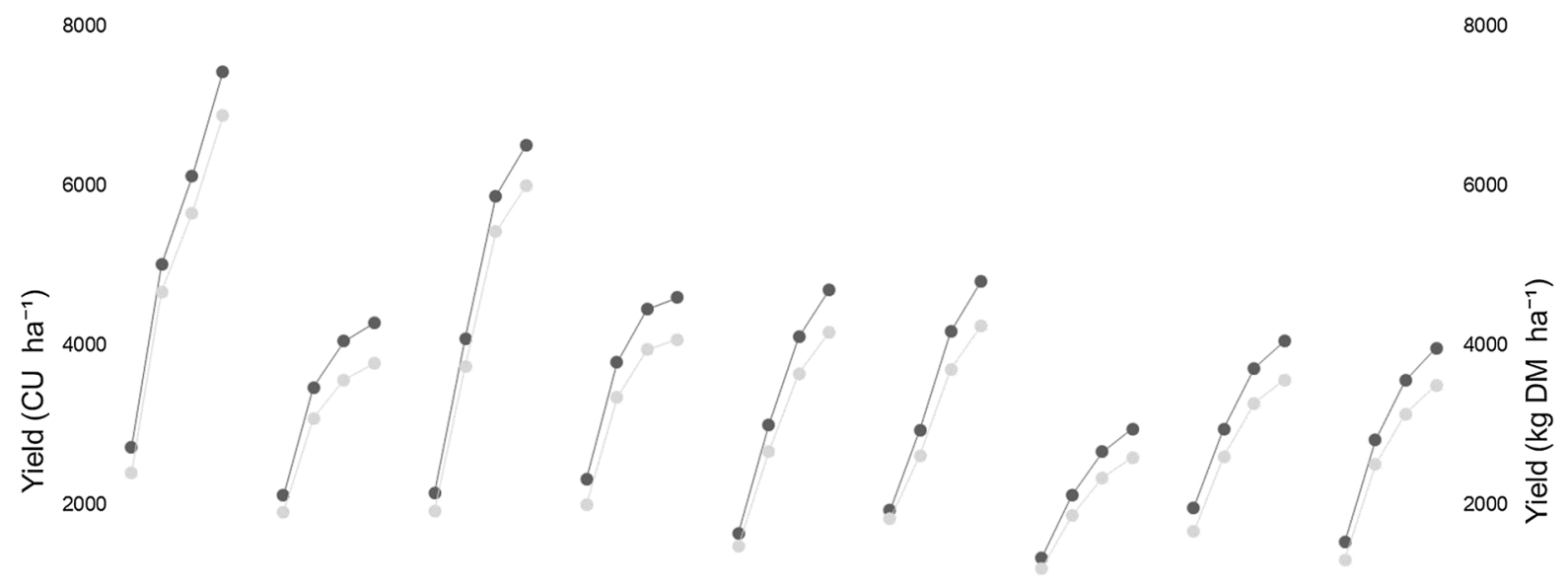

6000
${ }^{a}$ Hordeum vulgare

${ }^{\mathrm{b}}$ Brassica napus/rapa

${ }^{\mathrm{c}}$ Avena sativa

${ }^{\mathrm{d}}$ Triticum aestivum

${ }^{\mathrm{e}}$ Beta vulgaris

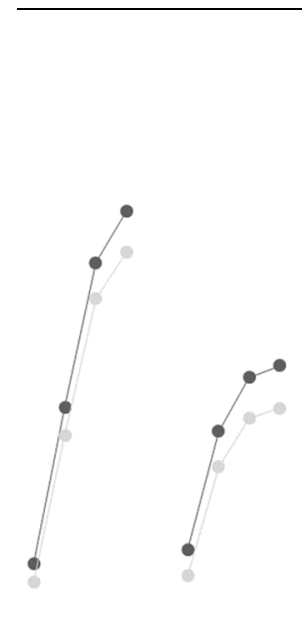

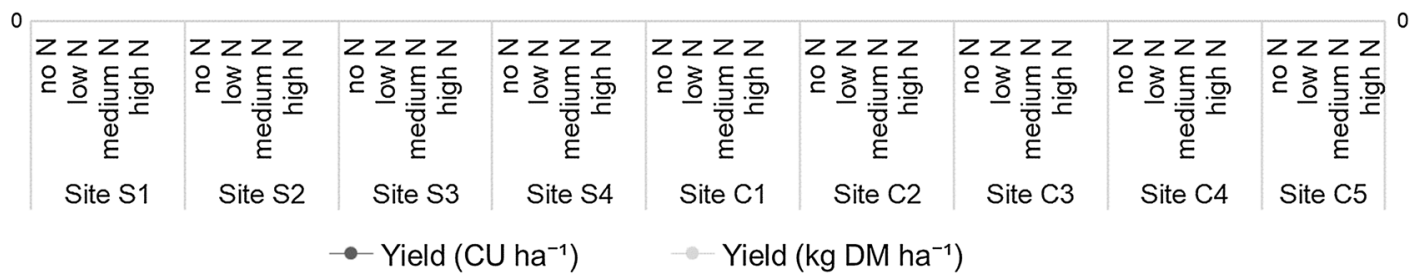

Fig. 2 Mean annual yields obtained at each site and $\mathrm{N}$ level, measured in cereal units (CU) ha ${ }^{-1}$ (dark grey) and dry matter (DM) ha ${ }^{-1}$ (light grey)

a crop rotation (Brankatschk and Finkbeiner 2015). It has also been used as a functional unit in LCAs comparing cropping systems (Prechsl et al. 2017). The CU represents the animal feeding value of each crop related to a reference crop (barley), and thereby enables crop yields to be represented by a unit that also considers crop function. One CU corresponds to $1 \mathrm{~kg}$ of fresh matter barley (at $14 \%$ moisture content). The animal feeding value is calculated based on protein, lipid, fibre and carbohydrate content of the crop, combined with data on animal species composition and species-specific metabolism. We used the $\mathrm{CU}$ values presented in the Supplementary Material of Brankatschk and Finkbeiner (2014), where calculation procedures are also presented in more detail. The relationship between harvested dry mass and $\mathrm{CU}$ harvested from the trial plots during the study period (1988-2009) is presented in Fig. 2. Subdivision of inputs and emissions among the crops in the rotation was not necessary in this study, since the aim was to 
assess the environmental impact over the whole crop rotation. Inventories were instead calculated for each treatment and year in the study period, and then aggregated over all years in the study period and divided by the amount of $\mathrm{CU}$ produced for each treatment during the study period. Amount of land occupied by crop cultivation was also determined by calculating the field area used per $\mathrm{CU}$ in each treatment.

\section{Activity and emissions data for life cycle inventory}

Most of the farm activity data were obtained from field measurements at the trial sites. They included data on harvested yield, soil carbon content, bulk density and soil texture. The study period chosen was 1988-2010, since data were readily accessible and consistent crop rotations were used for all sites during this period. Yields from 4 years in each time series were missing due to harvest failure, and these years were thus removed from the series at all sites in the two regions, to ensure consistent number of occurrences of each crop in each of the two crop rotations (see Table SM2 in Supplementary Material). Data that were not available from the field experiments, such as field operations, fertiliser types and pesticide amounts, were chosen to represent typical Swedish farming practices and, as far as possible, region-specific data were used. Specific data for all activities included are presented in this section.

The chosen emissions inventory for production of ammonium nitrate, triple superphosphate and potassium chloride was taken from the $\mathrm{GaBi}$ database (Fertilizers Europe 2018a, b, c; Brentrup et al. 2016), which is representative of mineral fertilisers produced in Europe. Assumed amounts of pesticide used were differentiated based on crop and cultivation region, using data from Statistics Sweden (2011). Emissions associated with pesticide production were taken from the ecoinvent database (Table 2).

Diesel consumption for ploughing was calculated using Eq. 1 (Arvidsson and Keller 2011) and diesel consumption values for the other field operations were taken from Lindgren et al. (2002). Assumed numbers of passes for each machine operation were differentiated according to crop (Table SM6 in Supplementary Material). Energy density and emissions data from production and use of diesel were taken from Gode et al. (2011).

$$
\begin{aligned}
& \text { Fuel consumption }\left(L_{h a^{-1}}\right) \\
& \quad=8.5+0.32 \times \text { clay content }(\%)
\end{aligned}
$$

Emissions from machinery production were calculated from the number of passes (see Table SM6 in Supplementary Material), data on $\mathrm{kg}$ machinery consumption per pass for each operation and emissions data for production of agricultural machinery from the ecoinvent database (Table 2).

Waterborne $\mathrm{N}$ emissions at field level (nitrate leaching) were calculated using a model implemented in the farm management tool VERA, developed by the Swedish Board of Agriculture, adapted to Swedish conditions and mainly based on empirical data. The model is described by Aronsson and Torstensson (2004) and calculates N leaching using site- and management-dependent typical leaching, and with correction factors for over- or under-fertilisation in relation to the yield achieved. Further information on the model structure and parameters used is provided in Supplementary Material to this paper. Phosphorus losses at field level were assumed to be equal to the region-, soil- and crop-specific average $\mathrm{P}$ losses, using data from Johnsson et al. (2016).

The emission factors for field-level volatilisation were set to 0.016 and $0.033 \mathrm{~kg} \mathrm{NH}_{3} \mathrm{~kg}^{-1} \mathrm{~N}$ fertiliser for soils with $\mathrm{pH}<7$ and $\mathrm{pH}>7$, respectively, and $0.04 \mathrm{~kg} \mathrm{NO}_{\mathrm{x}} \mathrm{kg}^{-1} \mathrm{~N}$ fertiliser, after recommendations from EMEP/EEA (2016). Direct soil $\mathrm{N}_{2} \mathrm{O}$ emissions were calculated using the equation for cumulative $\mathrm{N}_{2} \mathrm{O}$ emissions (Eq. 2) derived by Rochette et al. (2018), who tested field measurements from 474 treatment-years in Canada against different predictors. The equation utilises data on precipitation during the growing season, applied mineral fertiliser, soil sand content, soil $\mathrm{pH}$ and mean annual air temperature, and is thereby a more site-dependent model than the commonly used generic emission factors, such as Tier I values from IPCC (De Klein et al. 2006).

$$
\begin{aligned}
\mathrm{N}_{2} \mathrm{O}_{\text {direct }}= & e^{\wedge}(3.91+0.0022 * P(t)+0.0069 \\
& * \operatorname{MinN}(t)-0.0032 * \text { sand }-0.747 * p H \\
& \left.+0.0097 * T_{\text {air }}(t)\right)
\end{aligned}
$$

where $\mathrm{N}_{2} \mathrm{O}_{\text {direct }}\left(\mathrm{kg} \mathrm{N}_{2} \mathrm{O}-\mathrm{N}\right.$ ha $\left.{ }^{-1}\right)$ is annual cumulative soil $\mathrm{N}_{2} \mathrm{O}$ emissions from $\mathrm{N}$ fertiliser application, $P(\mathrm{~mm})$ is the precipitation during May to September, $\operatorname{MinN} \mathrm{N}_{2} \mathrm{O}_{\text {direct }}\left(\mathrm{kg} \mathrm{N}\right.$ ha $\left.^{-1}\right)$ is the mineral $\mathrm{N}$ applied, 
Table 2 Names of ecoinvent processes used for inventory data in this study. All inventories were taken from ecoinvent version 3.3, allocation: cut-off by classification

\begin{tabular}{ll}
\hline Ecoinvent process name & Used in this study for: \\
Pesticide production, unspecified, RER & Pesticide production emissions \\
Tillage, cultivating, chiselling, RoW & Machinery required for stubble cultivation \\
Tillage, ploughing, RoW & Machinery required for ploughing \\
Tillage, harrowing, by spring tine harrow, RoW & Machinery required for harrowing \\
Sowing, RoW & Machinery required for sowing \\
Fertilising, by broadcaster, RoW & Machinery required for applying fertiliser \\
Application of plant protection product, by field sprayer, RoW & Machinery required for applying pesticides \\
Combine harvesting, RoW & Machinery required for threshing \\
Harvesting, by complete harvester, beets, RoW & Machinery required for harvest/baling of sugar beet \\
Agricultural machinery production, unspecified, RoW & Production emissions per unit machinery \\
\hline
\end{tabular}

sand $\left(\mathrm{g} \mathrm{kg}^{-1}\right)$ is the sand content of the soil, $p H$ is the soil $\mathrm{pH}, T_{\text {air }}\left({ }^{\circ} \mathrm{C}\right)$ is the mean annual air temperature and $t$ is the year. Data for $P$ and $T_{\text {air }}$ were obtained from the Swedish Meteorological and Hydrological Institute (2018) by choosing the weather station closest to each site with available data for all years in the study period. Indirect soil $\mathrm{N}_{2} \mathrm{O}$ emissions were calculated by applying IPCC default emission factors to the calculated volatilised and leached N (De Klein et al. 2006).

The cereals in the rotations were assumed to be harvested at $17 \%$ moisture content at sites S1-S4 and $19 \%$ moisture content at sites $\mathrm{C} 1-\mathrm{C} 5$, and dried to $14 \%$ moisture content. Oilseed rape was assumed to be dried from 12 to $9 \%$ moisture content, while no drying or other post-harvest treatment of sugar beet was included, since this typically occurs after farm-gate. The energy consumption during crop drying was assumed to be $0.15 \mathrm{~L}$ of heating oil per $\mathrm{kg}$ of water removed and $19 \mathrm{kWh}$ of electricity per ton grain (Edström et al. 2005). Life cycle emissions data for heating oil were taken from (Gode et al. 2011) and data on the Swedish electricity mix from (Brander et al. 2011).

Organic carbon concentration in the topsoil $(0-20 \mathrm{~cm})$ was measured 6-10 times in every treatment during the whole trial lifetime (1956-2011), and we opted to use these data to derive mean SOC changes. This was done by estimating the slope for SOC concentration measurements over time for each treatment using linear regression analysis (see regression plots in Fig. SM1). Annual carbon stock changes in the topsoil were then estimated from the slope and site-specific bulk density values. The choice to include a longer time period for the SOC change estimation was made to avoid unfair allocation between years in the study period and because there were too few measurements during the study period. This should be considered when interpreting calculated SOC changes, and for this reason we report and discuss both total estimated GHG emissions and GHG emissions from non-SOC processes.

Seed production was included by subtracting corresponding seed rates from yield. Assumed seed rate for barley was $170 \mathrm{~kg} \mathrm{ha}^{-1}$, for wheat and oats $210 \mathrm{~kg} \mathrm{ha}^{-1}$ and for oilseed rape $6 \mathrm{~kg} \mathrm{ha}^{-1}$ (Ahlgren et al. 2009). It was assumed that $60 \mathrm{~kg}$ sugar beet were required to produce the $2.1 \mathrm{~kg}$ seeds needed per ha (Nemecek and Schnetzer 2011a, b).

Liming rates in the experiments were very low (on average $0.1-0.15 \mathrm{~kg} \mathrm{CaO} \mathrm{ha}{ }^{-1}$ year $^{-1}$ ) during the study period and it was therefore not considered relevant to include impacts of liming.

Life cycle impact assessment

The GHGs carbon dioxide $\left(\mathrm{CO}_{2}\right)$, methane $\left(\mathrm{CH}_{4}\right)$ and $\mathrm{N}_{2} \mathrm{O}$ were included in the assessment, and their climate impacts were calculated using the IPCC characterisation factors (including climate-carbon feedbacks) for $\mathrm{GWP}_{100}$ reported by Myhre et al. (2013).

The marine eutrophication impact of waterborne $\mathrm{N}$ and $\mathrm{P}$ losses at field level was calculated using the method described by Henryson et al. (2018). This 
method uses site-dependent characterisation factors, which express the impact in $\mathrm{N}$ equivalents $\left(\mathrm{N}_{\mathrm{eq}}\right)$ and account for retention of nutrients along their way to marine environments, as well as the limiting nutrient in the marine recipient, while most other marine eutrophication life cycle impact assessment (LCIA) methods only account for $\mathrm{N}$ additions. In contrast to the majority of marine recipients, the sub-basins of the Baltic Sea surrounding Sweden can be growth limited by either N or P, or both (Swedish EPA 2006). Impacts of other $\mathrm{N}$ emissions were calculated using the ReCiPe2008 LCIA method (Struijs et al. 2013). Waterborne $\mathrm{P}$ emissions during fertiliser production were assumed to occur at Yara's Siilinjärvi phosphate mine in Eastern Finland, which is Europe's only phosphate mine and thereby the only source from which P-containing production effluent could end up in the Baltic Sea. This assumption therefore represents the worst case in terms of the marine eutrophication impact of $\mathrm{P}$ emissions during fertiliser production. Retention of $98 \%$ was assumed for P-containing effluent from Siilinjärvi (Huttunen et al. 2013). All other $\mathrm{P}$ emissions were assumed to be emitted at locations where they would not reach a P-limited marine environment and were therefore not included.

\section{Statistical analyses}

The mean impacts for each $\mathrm{N}$ level and site were calculated as the mean impacts per CU produced, which involved accounting for the fact that each treatment produced different outputs. The approach described in Eq. 3 was therefore used to calculate mean impacts:

Mean impact $_{i, k}=\frac{\sum_{a=1}^{A}\left(\text { Impact }_{i, k, a} * \text { Yield }_{k, a}\right)}{\sum_{a=1}^{A} \text { Yield }_{k, a}}$

where $k$ is a site or $\mathrm{N}$ level, $i$ is impact category and $A$ is all sites when $k$ is an $\mathrm{N}$ level and all $\mathrm{N}$ levels when $k$ is a site.

One-way ANOVA analysis with a randomised block design was used to investigate whether $\mathrm{N}$ level or site affected the mean for each impact category. The impacts for each treatment were normalised for yield according to Eq. 4 before performing the ANOVA analysis, to keep consistency with calculation of the means. This procedure ensured that treatments were fairly weighted according to how they contributed to the mean impact, and that the mean impacts tested for in the ANOVA analysis were consistent with the mean impacts according to Eq. 3. Since the normalisation generated two sets of normalised impacts, the effects of $\mathrm{N}$ level and site were analysed by separate ANOVA analyses. The significance level was set to 0.05 .

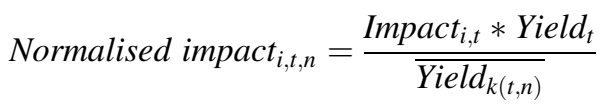

where $i$ is the impact category, $t$ is the treatment (any combination of $\mathrm{N}$ level and site), $n$ is the normalisation variable (i.e. site when the effect of site was analysed and $\mathrm{N}$ level when the effect of $\mathrm{N}$ level was analysed) and $k(t, n)$ is the treatment site or $\mathrm{N}$ level. The results from the ANOVA analysis were followed up by Tukey's HSD (Honestly Significant Difference) test for $\mathrm{N}$ level.

In addition to the ANOVA, a simple sensitivity analysis was performed for direct soil $\mathrm{N}_{2} \mathrm{O}$ emissions and waterborne soil $\mathrm{N}$ emissions, since these were modelled and expected to contribute substantially to the estimated impacts. The sensitivity analysis was performed by changing the modelled direct soil $\mathrm{N}_{2} \mathrm{O}$ emissions and waterborne $\mathrm{N}$ emissions one at a time by $20 \%$.

Statistical analyses was performed using the software R version 3.5.1. All results from statistical tests are provided in the Supplementary Material (Tables SM9-SM12).

\section{Results}

The results revealed large variations between sites and $\mathrm{N}$ levels in both impact categories. Estimated total GHG emissions varied from 260 to $1280 \mathrm{~g}$ $\mathrm{CO}_{2 \mathrm{eq}} \mathrm{CU}^{-1}$ between all treatments, and from 200 to $1040 \mathrm{~g} \mathrm{CO}_{2 \mathrm{eq}} \mathrm{CU}^{-1}$ when SOC changes were excluded (Fig. 3). Maximum difference in non-SOC GHG emissions between sites within the $\mathrm{N}$ levels was 170, 250 and $330 \%$ for low, medium and high $\mathrm{N}$, respectively, while the maximum difference between $\mathrm{N}$ levels within sites was $13-74 \%$. Thus, variation between sites was larger than variation between $\mathrm{N}$ levels (Fig. 3). The highest $\mathrm{N}$ level gave the highest non-SOC GHG emissions for all sites, but the order for low and medium $\mathrm{N}$ levels varied between sites. SOC losses generally contributed to large GHG emissions 


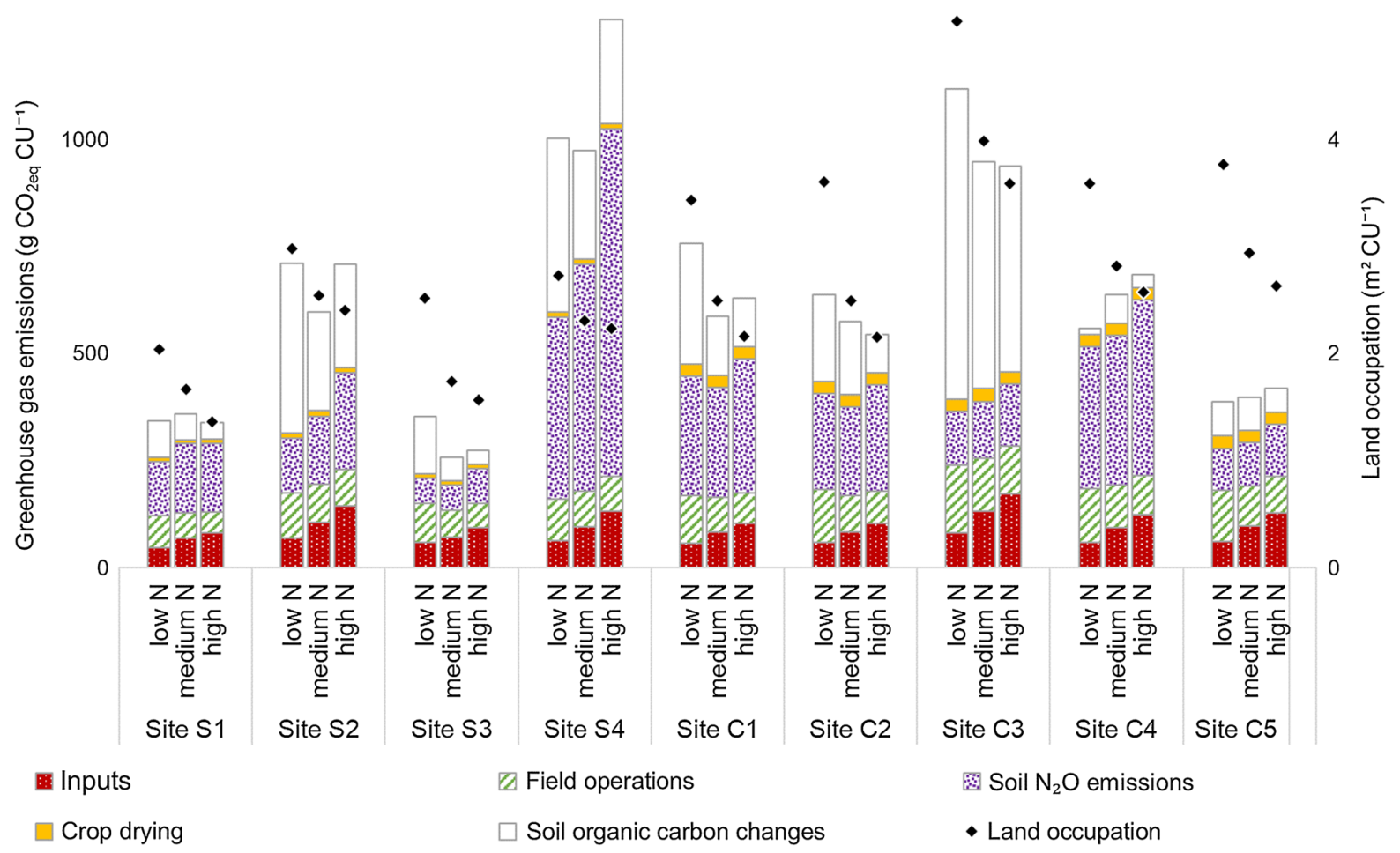

Fig. 3 Greenhouse gas (GHG) emissions and land area occupied by crop cultivation at the four southern Swedish sites (S1-S4) and five central Swedish sites (C1-C5) under three

(2.6-65\% of total GHG emissions) compared with other emission sources, and including SOC changes therefore influenced which $\mathrm{N}$ level minimised GHG emissions. Unlike the combined impact of other emission sources, the contribution of SOC changes generally decreased with higher $\mathrm{N}$ level. The combined effect of SOC changes and other emission sources was that the optimum $\mathrm{N}$ level in terms of minimising total GHG emissions was low, medium or high depending on site.

Mean total GHG emissions were 620, 560 and $600 \mathrm{~g} \mathrm{CO}_{2 \text { eq }} \mathrm{CU}^{-1}$ for the low, medium and high $\mathrm{N}$ level, respectively, or 380,400 and $480 \mathrm{~g}$ $\mathrm{CO}_{2 \mathrm{eq}} \mathrm{CU}^{-1}$, respectively, when SOC changes were excluded (Fig. 3). However, differences between $\mathrm{N}$ level means were not statistically significant for total GHG emissions, and differences between low and medium $\mathrm{N}$ level means were not statistically significant when SOC changes were excluded (Tables SM10-SM11). Mean GHG emissions for the different nitrogen $(\mathrm{N})$ fertiliser intensities, where high $\mathrm{N}$ is closest to current common practice

sites varied between 290 and $1090 \mathrm{~g} \mathrm{CO}_{2 \mathrm{eq}} \mathrm{CU}^{-1}$ for total GHG emissions, or 220 and $800 \mathrm{~g} \mathrm{CO}_{2 \mathrm{eq}} \mathrm{CU}^{-1}$ when SOC changes were excluded (Fig. 3). In contrast to the differences between $\mathrm{N}$ level means, the differences between site means were highly statistically significant for both total GHG emissions and non-SOC GHG emissions (Table SM10).

Marine eutrophication varied from 2.0 to $9.9 \mathrm{~g}$ $\mathrm{N}_{\mathrm{eq}} \mathrm{CU}^{-1}$ (Fig. 5), with a maximum difference of $300 \%, 330 \%$ and $390 \%$ between sites at the low, medium and high $\mathrm{N}$ levels, respectively, and a maximum difference of $7-59 \%$ between $\mathrm{N}$ levels at different sites. Thus, similarly to the results for GHG emissions, differences between $\mathrm{N}$ levels were generally smaller than differences between sites. The medium $\mathrm{N}$ level gave the lowest marine eutrophication at all central sites (C1-C5) and one of the southern sites (S3), while the low $\mathrm{N}$ level gave the lowest marine eutrophication at the remaining three southern sites. The high $\mathrm{N}$ level gave the highest impact at five 
of the sites and the lowest $\mathrm{N}$ level at the remaining four sites. Mean marine eutrophication was 4.4, 4.2 and $5.0 \mathrm{~g} \mathrm{~N}_{\mathrm{eq}} \mathrm{CU}^{-1}$ for the low, medium and high $\mathrm{N}$ level, respectively (Fig. 5), but only the difference between medium and high $\mathrm{N}$ levels was statistically significant (Table SM11 in Supplementary Material). In contrast, differences between site means were highly statistically significant (Table SM10) and varied between 2.1 and $9.1 \mathrm{~g} \mathrm{~N}_{\mathrm{eq}} \mathrm{CU}^{-1}$.

The sensitivity analysis showed that altering soil $\mathrm{N}_{2} \mathrm{O}$ emissions by $20 \%$ changed estimated non-SOC GHG emissions by $3.0-15 \%$ (average $8.3 \%$ ) for the respective treatments. The effect on total GHG emissions was slightly smaller (range $1.1-12 \%$, average $6.3 \%$ ). Changing waterborne field $\mathrm{N}$ emissions by $20 \%$ had a smaller effect on both non-SOC GHG emissions (range $0.2-1.7 \%$, average $1.3 \%$ ) and total GHG emissions (range $0.3-3.3 \%$, average $0.8 \%$ ). However, it had a larger effect on estimated marine eutrophication, which changed by $6.7-19.6 \%$ (average $16 \%$ ) for the respective treatments. Full results of the sensitivity analysis are available in Table SM12.

Land area occupied by crops was inversely proportional to the amount of $\mathrm{CU}$ produced and therefore declined with higher $\mathrm{N}$ level. However, the rate of decline was smaller between medium and high $\mathrm{N}$ levels than between low and medium $\mathrm{N}$ levels (Fig. 3). Mean land occupation was 3.0, 2.3 and $2.1 \mathrm{~m}^{2}$ year $\mathrm{CU}^{-1}$ for low, medium and high $\mathrm{N}$ level, respectively. Mean land occupation for the sites varied between 1.6 and $3.9 \mathrm{~m}^{2}$ year $\mathrm{CU}^{-1}$.

\section{Discussion}

Greenhouse gas emissions

The estimated GHG emissions differed between sites, both in terms of differences between $\mathrm{N}$ levels and in terms of magnitude. A feature in common for the sites which had the lowest non-SOC GHG emissions at medium $\mathrm{N}$ level (S3, C1 and C2) instead of low $\mathrm{N}$ level was that they showed a relatively high difference in yield between the low and medium $\mathrm{N}$ level (Fig. 2). This yield difference was thereby sufficiently large to outweigh the increase in emissions per unit area. Among the southern sites, high-yielding sites (S1 and S3) had lower GHG emissions than low-yielding sites, whereas this was not observed for the central sites, where the low-yielding site $\mathrm{C} 3$ had the second lowest non-SOC GHG emissions (Figs. 2 and 6). One of the reasons for this was the magnitude of yield differences between low- and high-yielding sites (Fig. 2). Another reason was that the high-yielding central sites $(\mathrm{C} 1$ and C2) had relatively high soil $\mathrm{N}_{2} \mathrm{O}$ emissions per hectare, which in turn was mainly due to their low sand content. There was no consistent difference in the magnitude of GHG emissions between southern and central sites, which indicates that soil characteristics may be more important for GHG emissions than geographical location, at least within the ranges of $\mathrm{N}$ fertiliser rates considered here.

The major contributing factor to the variation in non-SOC GHGs was soil $\mathrm{N}_{2} \mathrm{O}$ emissions. Field-level $\mathrm{N}_{2} \mathrm{O}$ emissions have previously been shown to be the main contributor to GHG emissions from crop cultivation (Goglio et al. 2014), and this was confirmed by our results to a certain extent, although the importance of soil $\mathrm{N}_{2} \mathrm{O}$ emissions differed between treatments (26-78\% of total non-SOC GHGs; Fig. 3). Differences in soil $\mathrm{N}_{2} \mathrm{O}$ emissions were also larger between sites (up to $900 \%$ ) than between $\mathrm{N}$ levels (up to $90 \%$ ). However, the most common approach for calculating soil $\mathrm{N}_{2} \mathrm{O}$ emissions in LCA is to use default emission factors from IPCC Tier I methodology (De Klein et al. 2006), which neglect all local factors such as soil characteristics and weather and instead assume that $1 \%$ of the applied mineral fertiliser $\mathrm{N}$ is emitted as direct $\mathrm{N}_{2} \mathrm{O}$, regardless of other factors. Since site characteristics have been shown to be highly important for $\mathrm{N}_{2} \mathrm{O}$ emissions (Rochette et al. 2018), the IPCC Tier I emission factors have been shown to be a poor predictor of $\mathrm{N}_{2} \mathrm{O}$ emissions at field scale (Goglio et al. 2018). Instead, we used a model derived from meta-analysis of field measurements in Canada, where for example precipitation was identified as an even more important variable than $\mathrm{N}$ rate supplied (Rochette et al. 2018). Despite not being verified on a global scale, this model should give better estimates than global emissions factors of field-level $\mathrm{N}_{2} \mathrm{O}$ emissions in cold temperate regions like Sweden. Applying the field data-based model to our treatments gave emissions factors of $0.4-6.3 \%$ (fraction of added $\mathrm{N}$ fertiliser emitted as direct $\mathrm{N}_{2} \mathrm{O}$ ), with variations between sites and $\mathrm{N}$ levels. The results highlight the importance of using site-dependent emission models when comparing spatially dependent processes at different sites, as recommended by others (Peter et al. 
2016) but still rarely used for estimating soil $\mathrm{N}_{2} \mathrm{O}$ emissions in LCAs.

All soils, regardless of $\mathrm{N}$ level and site, displayed a likely SOC loss during the study period. We base this discussion section on the mean values derived in the regression analysis, but uncertainties in SOC change estimations were high (Fig. 4), which is discussed further in "Uncertainties" section. Seven of the sites had their smallest mean SOC loss per CU at the highest $\mathrm{N}$ level and their highest SOC loss per CU at the lowest $\mathrm{N}$ level. The decreasing SOC loss per CU at higher $\mathrm{N}$ level was due to slightly lower mean SOC loss per ha (Fig. SM2) and to higher yield output (Fig. 2) and thus a smaller fraction of per ha SOC loss being allocated to each CU produced. Since SOC loss contributed a large fraction of the GHG emissions, these results affected the conclusions regarding which $\mathrm{N}$ level was optimal from a GHG emissions perspective. The lowest total GHG emissions were achieved at the highest $\mathrm{N}$ level for two of the sites, at the medium $\mathrm{N}$ level for five of the sites and at the low $\mathrm{N}$ level for two of the sites. The results were thus very divergent and no general conclusions on the optimum $\mathrm{N}$ level for minimising GHG emissions can be drawn, especially considering that there were no statistically significant differences between the $\mathrm{N}$ level means when SOC was included (Table SM10). These results illustrate the complex interplay between different variables affecting GHG emissions from cropping systems.

Marine eutrophication

The contribution of soil emissions of $\mathrm{N}$ and $\mathrm{P}$ dominated the marine eutrophication results (Fig. 5), and differences between sites were therefore mainly explained by differences in estimated field emissions and their characterisation in the LCIA. Field N losses were in turn dominated by the waterborne component ( $>93 \%$ of the total impact of field $\mathrm{N}$ losses for all treatments), which means that total estimated marine eutrophication impact is highly sensitive to the choice of model for waterborne $\mathrm{N}$ emissions at field level. In LCAs, nitrate leaching is generally estimated using simple models that neglect spatial characteristics such as soil type and climate (Nitschelm et al. 2017), despite their significant contribution to leaching magnitude observed here (Table SM8 in Supplementary Material). Although $\mathrm{P}$ losses on average

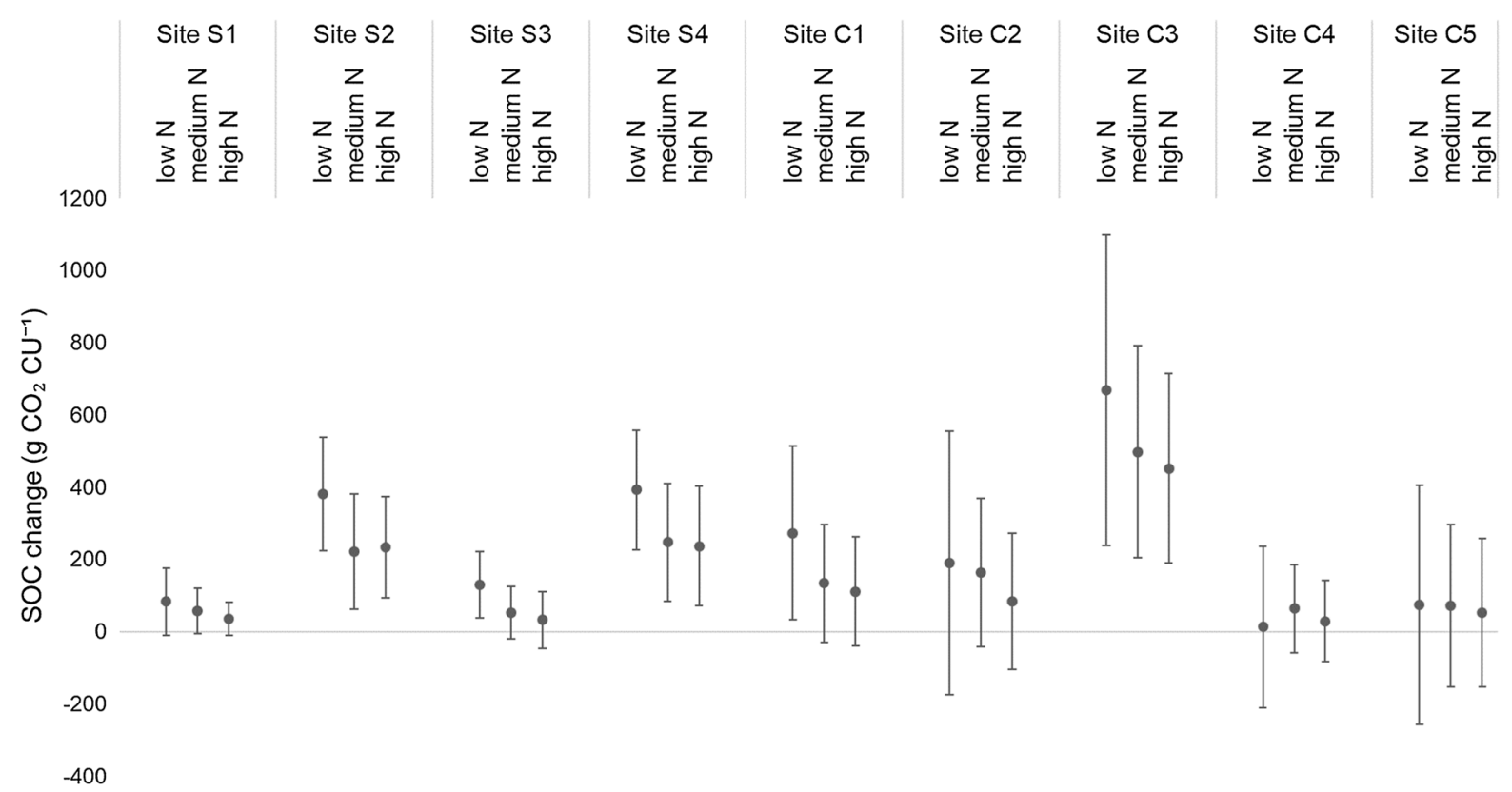

Fig. 4 Estimated annual emissions of $\mathrm{CO}_{2} \mathrm{CU}^{1}$ from soil organic carbon (SOC) changes at the four southern Swedish sites (S1-S4) and five central Swedish sites (C1-C5) under three different nitrogen $(\mathrm{N})$ fertiliser intensities, where high $\mathrm{N}$ is closest to current common practice. The emissions estimates were derived through regression analysis of measured SOC levels in the topsoil. The bars represent the confidence intervals at $95 \%$ confidence level 
12

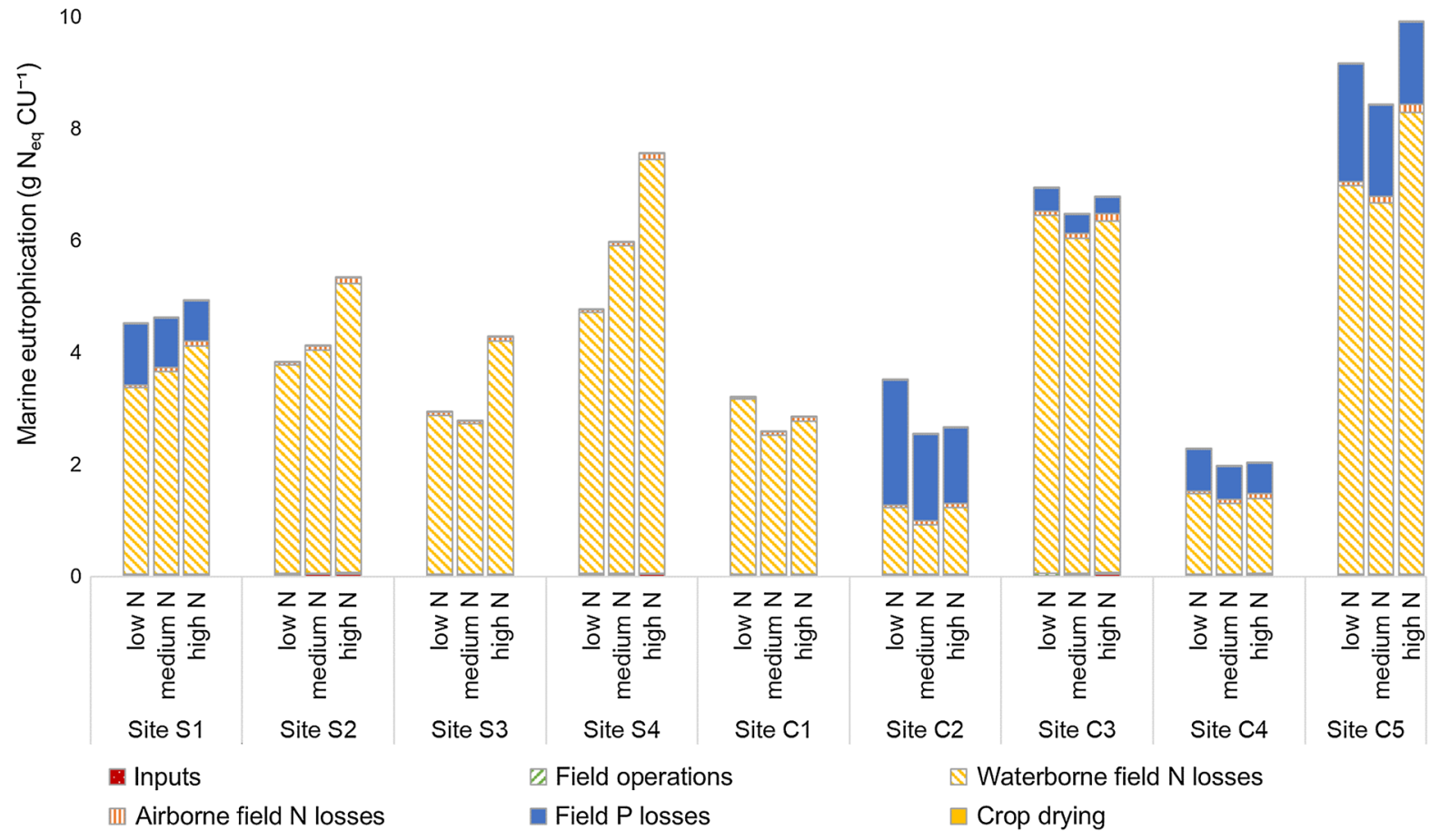

Fig. 5 Marine eutrophication impact from crop cultivation at the four southern Swedish sites (S1-S4) and five central Swedish sites (C1-C5) under three different nitrogen $(\mathrm{N})$ fertiliser intensities, where high $\mathrm{N}$ is closest to current common practice

contributed considerably less to the marine eutrophication impact than $\mathrm{N}$, the contribution was $67 \%$ of the marine eutrophication for one of the treatments (low $\mathrm{N}$ level at site $\mathrm{C} 2$ ), which in this case was explained by the high clay content in combination with a relatively high characterisation factor. Marine eutrophication LCIA models tend to focus on $\mathrm{N}$ emissions and neglect P emissions (see e.g. Struijs et al. 2013; Cosme and Hauschild 2017), since a majority of global marine recipients are $\mathrm{N}$-limited. However, neglecting $\mathrm{P}$ can underestimate the impact when the recipient is P-limited or co-limited in $\mathrm{P}$ and $\mathrm{N}$, as is the case for some of our sites (see values for e.g. site C2). Ignoring the contribution of $\mathrm{P}$ to marine eutrophication in the present study would have identified $\mathrm{C} 2$ as a site with low marine eutrophication contribution due to its clayey soil (Table SM1), giving high $\mathrm{P}$ leaching but low $\mathrm{N}$ leaching. The results in the present study clearly illustrate that the selection of emissions and LCIA models is important for assessment outcomes.
Correlations and trade-offs between greenhouse gas emissions and marine eutrophication

The GHG emissions varied by a factor of five between treatments, and the variation was similar for marine eutrophication. However, results for the two impact categories generally exhibited different patterns, both in terms of $\mathrm{N}$ level ranking at each site and in terms of ranking of site means (Figs. 3, 5 and 6). This indicates that although yield responses can have a large influence on the results, as previously shown by e.g. Brentrup et al. (2004) and Wang et al. (2016), sitespecific emission profiles are also highly important.

Mean impacts were lowest at the medium $\mathrm{N}$ level for both GHG emissions and marine eutrophication (Fig. 6), but only two individual sites (S3 and C1) had their lowest impact at the medium $\mathrm{N}$ level for both GHGs and marine eutrophication (Figs. 3 and 5). This outcome highlights the importance of choosing an appropriate spatial scale with respect to the question to be answered in order to attain relevant LCA results. 
Fig. 6 Mean environmental impacts for nitrogen $(\mathrm{N})$ fertiliser levels and sites (arranged by ascending non-soil organic carbon (SOC) greenhouse gas (GHG) emissions). Black dots represent total GHG emissions, blue circles represent non-SOC GHG emissions and orange triangles represent marine eutrophication. (Color figure online)

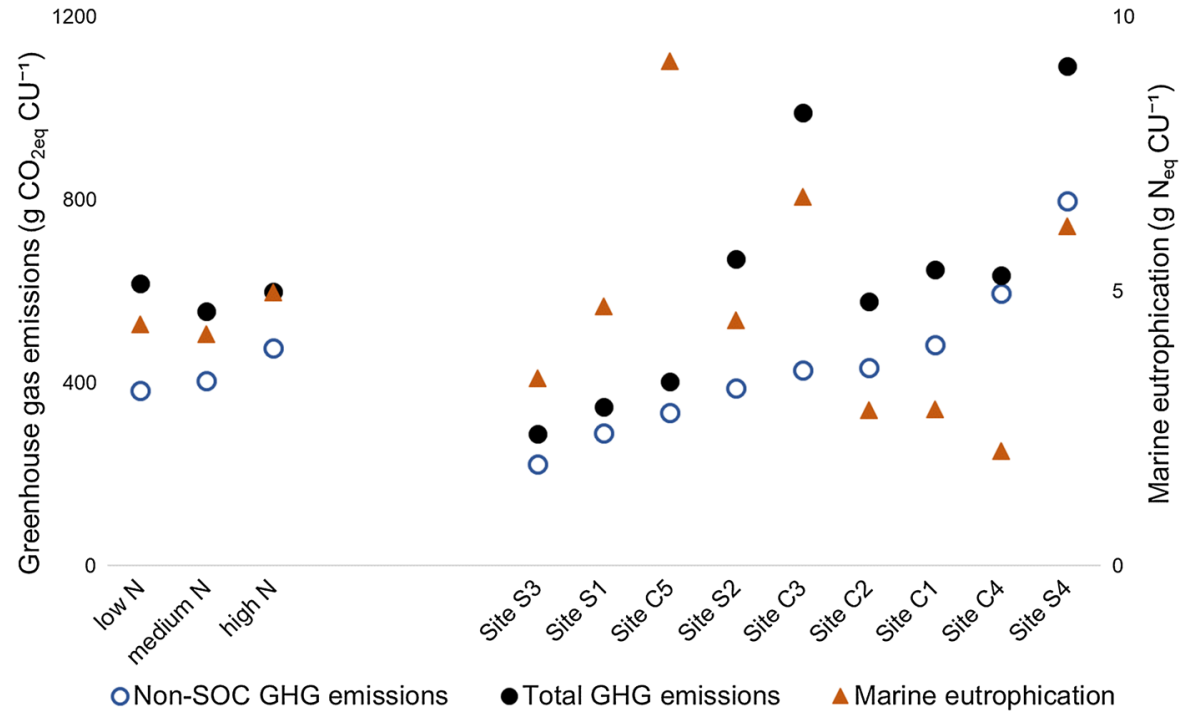

Similarly, previous studies have found that impacts were smallest at the lowest (Ashworth et al. 2015; Goglio et al. 2012; Brentrup et al. 2004), medium (Ruan et al. 2016; Wang et al. 2016) or highest (Charles et al. 2006) $\mathrm{N}$ fertiliser rate tested in each study. While the methods, models and assumptions differ between these studies, site-related differences may also explain why they reach different conclusions.

Despite climate impact gaining most of the attention as the dominant environmental issues of our time, waterborne reactive $\mathrm{N}$ losses are estimated to impose greater costs in the EU, through damage to human health and ecosystems, than the climate impact caused by $\mathrm{N}_{2} \mathrm{O}$ emissions (Sutton et al. 2011). As Fig. 6 illustrates, there were trade-offs between GHG emissions and marine eutrophication at some sites, which means that aspects that decreases GHG emissions does not necessarily decrease marine eutrophication. Although the major process contributions to both impact categories (soil $\mathrm{N}_{2} \mathrm{O}$ emissions, SOC changes, waterborne $\mathrm{N}$ and $\mathrm{P}$ losses) are dependent on the same factors (soil characteristics, climate, fertilisation, yield), they were clearly influenced in different ways at different sites. For example, sand content is reported to be a reducing factor for $\mathrm{N}_{2} \mathrm{O}$ emissions, while a high soil sand content increases the risk of $\mathrm{N}$ leaching (Rochette et al. 2018; Kyllmar et al. 2006). This effect is evident for the sandy soil at site $\mathrm{C} 3$, where soil $\mathrm{N}_{2} \mathrm{O}$ emissions were low while $\mathrm{N}$ leaching was high (Figs. 3 and 5). However, the connection to soil texture was not consistent for all sites, since both $\mathrm{N}_{2} \mathrm{O}$ emissions and $\mathrm{N}$ leaching per unit produced are also affected by other factors such as climate and yield response. For example, the increase in both GHG emissions and marine eutrophication from medium to high $\mathrm{N}$ level at site $\mathrm{S} 2$ and site $\mathrm{S} 4$ can be explained by the weak yield response (Fig. 2), which in turn may be an indication that factors other than $\mathrm{N}$ fertiliser limited growth in those treatment.

\section{Uncertainties}

Data from long-term field trials are a valuable resource for life cycle assessments, since the availability of empirical data decreases the dependence on models and their associated uncertainties. However, using measured data also means that variations due to e.g. crop disease and extreme weather events are embodied in the results. There are also uncertainties connected to measuring methods, which could be one reason for the large uncertainties in estimated SOC change (Fig. 4). A similar pattern where field data exhibited larger variability than modelled data was observed by Goglio et al. (2018). Although the farming practices used in the Swedish long-term field trials represent typical farming practices in terms of crop rotation, field operations and amount of inputs, a typical farmer would adapt e.g. crop choice and annual fertiliser amounts to yearly conditions and cumulative experience, instead of leaving cropping system management unchanged over more than 60 years. For that reason, 
the quantitative results from this study should not be interpreted as a benchmark for average Swedish crop cultivation, or as representing the environmental impact of an ideal cropping system at each individual site. On the other hand, consistent management at the different sites over time enabled differences arising from site-dependent characteristics to be distinguished.

Despite LCA being an ISO standardised methodology (ISO 2006), performing an LCA requires making methodological choices, which could significantly affect the outcomes of the study. One such choice is the functional unit, which is particularly complicated for agricultural systems due to their multiple functions and outputs (Brankatschk and Finkbeiner 2015; Notarnicola et al. 2017). Cereal unit has been applied as the functional unit in at least one other LCA of crop rotations, is used in some national agricultural statistics and accounts for the most important nutritional functions of crops (Brankatschk and Finkbeiner 2014; Prechsl et al. 2017). It was therefore deemed appropriate for the present study. Drawbacks of using CU as the functional unit are that the values are based on animal feeding value although not all crops are used for animal feed, and that the data on livestock species composition are based on German conditions. However, since more Swedish cereals are used for animal feed than for human consumption (Eklöf 2014), and since livestock species composition in Germany and Sweden are similar (FAO 2016), this compromise was considered acceptable in the present study. Charles et al. (2006) included a quality criterion in their LCA of wheat cultivation, which is relevant since fertiliser management affects protein content in harvested crops, but difficult to apply when assessing whole crop rotations, since different characteristics are valued in different crops. In addition, low-quality crops are not always discarded but instead used for other purposes, e.g. low-protein wheat can be used as animal feed or for biofuel production. We therefore chose not to include any crop quality criteria in this study, although it should be noted that the quality aspect should be considered when evaluating appropriate fertiliser management in a decision-making context.

Environmental impacts of agricultural systems are dominated by soil emissions, which in turn are sitedependent (Notarnicola et al. 2017). Since measured emission data are rarely available, the reliability of
LCA outcomes depends on the availability of emission models that can be applied with existing data. Our sensitivity analysis showed that estimated GHG emissions were highly sensitive to changes in soil $\mathrm{N}_{2} \mathrm{O}$ emissions. Feasible models for estimating $\mathrm{N}_{2} \mathrm{O}$ emissions at field scale are scarce, mainly due to emissions being highly variable over time and space (Butterbach-Bahl and Dannenmann 2011), which is why the crude Tier I model presented by IPCC (De Klein et al. 2006) is used in most crop LCAs. The model used to estimate soil $\mathrm{N}_{2} \mathrm{O}$ emissions in this study was instead derived from a meta-analysis of Canadian field trials, and has not been verified for Swedish conditions. While this is an important source of uncertainty in the quantitative results, it should give a more realistic representation of differences in emissions between sites than using a site-independent emission factor. Similarly, marine eutrophication was highly sensitive to changes in nitrate leaching, since this emission dominated the impacts assessed. The model used for estimating nitrate leaching is based on data derived from national reporting, together with correction factors for fertiliser rates over or under optimum level originally developed for a national farmer's advisory tool in Sweden. Considering the large contribution of soil $\mathrm{N}_{2} \mathrm{O}$ and nitrate emissions to these two important impact categories, harmonised models that are globally applicable but still account for spatial and management variations would improve both the accuracy and inter-comparability of crop LCAs.

The third largest contributor to the impacts assessed was SOC changes, which are uncertain both in terms of methodological choice (see Methods section) and in terms of empirical data (Fig. 4). The confidence intervals of both SOC change per ha (Fig. SM2) and resulting $\mathrm{CO}_{2}$ emissions per $\mathrm{CU}$ (Fig. 4) exhibited considerable overlap, which complicates interpretation of the results. Modelling SOC dynamics instead of using measured values would be an option to achieve more stable results, but would also introduce new uncertainties associated with the chosen model and methodological choices such as temporal system boundary and choice of initial SOC level. Measured data were therefore chosen as the least biased way to represent results, in accordance with recommendations by Goglio et al. (2015), but the large confidence intervals mean that interpretation of observed impacts due to SOC changes is uncertain. 
Implications and perspectives

While the medium $\mathrm{N}$ level had the lowest GHG emissions and marine eutrophication impact, it required more land per unit produced than the high $\mathrm{N}$ level (Figs. 3 and 6). Agricultural land is a limited resource, so reducing the area of land required for producing a unit of crops can potentially prevent land use change, or free up space for environmental impact mitigation measures. Examples of these mitigation measures are constructed wetlands to retain nutrients (Land et al. 2016) and producing biomass that promotes soil carbon sequestration and replaces fossil fuels (Hammar et al. 2014; Prade et al. 2014). Several recent studies have indicated high climate mitigation potential of reducing land requirements through agricultural intensification (Balmford et al. 2018; Searchinger et al. 2018), while others claim that yield improvements do not necessarily mean that less cropland is actually used (Lambin and Meyfroidt 2011). These discrepancies highlight the importance of considering the system beyond the field scale in order to make a fair assessment of the environmental consequences of different management practices. However, the results presented in this study show that the field-level environmental performance response to different fertiliser intensities is site-dependent, which is potentially also the case for other proposed intensification measures, such as altering tillage practices or introducing catch crops (see e.g. Doltra and Olesen 2013; Zaher et al. 2013). The highly site-dependent nature of agricultural systems is therefore relevant to consider when evaluating the mitigation potential of intensification strategies at larger scales.

Site-dependent effects of management practices and management change have been reported previously (Goglio et al. 2014). The difference in impact magnitude and preferred $\mathrm{N}$ level for minimising impacts at sites located geographically close to each other in this study (Figs. 1, 3 and 5), as well as other patterns in the results, indicate that soil texture was one of the most important variables. This outcome indicates possibilities for decreasing the environmental impact by considering soil characteristics when planning e.g. crop rotations and fertiliser strategy, as farmers already do to maximise profit. Since soil texture can vary even within fields, it is also possible that precision fertilisation could have a significant effect on the overall environmental impact (Delin and
Stenberg 2014). However, further research is needed to identify factors that can be used to characterise sites in terms of their environmental impact profile. The variations in environmental impact between sites in this study illustrate how using emissions and impact assessment models operating at a relevant spatial scale in relation to the research question improves the possibility of drawing relevant conclusions.

\section{Conclusions}

This study explored the influence of site and $\mathrm{N}$ fertiliser rate on the GHG emissions and marine eutrophication impact from crop cultivation in a life cycle perspective. Results from a 20-year assessment at nine sites and three $\mathrm{N}$ fertiliser levels revealed that site affected the $\mathrm{N}$ level that gave the lowest impacts and the impact level in general, and that results were also not consistent between impact categories. This outcome illustrates that general management plans for decreasing the environmental impact of crop cultivation will have difficulty succeeding without considering site characteristics and potential trade-offs between different impacts.

Overall, the results showed that site influenced GHG emissions and marine eutrophication more than $\mathrm{N}$ level did, at least for the moderate fertiliser rates studied here. The medium $\mathrm{N}$ level, which was lower than current average rate in the study regions, gave on average the lowest total GHG emissions and marine eutrophication. However, differences between mean impacts at each $\mathrm{N}$ level were small (up to $10 \%$ for GHG emissions and 20\% for marine eutrophication) and not statistically significant for total GHG emissions, and only significant between medium and high $\mathrm{N}$ level for marine eutrophication. In contrast to the moderate differences observed between $\mathrm{N}$ levels, differences between mean impacts at the different sites were large (up to $280 \%$ for GHG emissions and $340 \%$ for marine eutrophication) and statistically significant for both impact categories. These results show that site-specific information can improve the accuracy of assessments of the environmental impact of crop cultivation and thereby generate better decision support.

Acknowledgements The authors would like to thank Claudia von Brömssen at the Department of Energy and Technology, 
Swedish University of Agricultural Sciences, for providing guidance on the statistical analyses. Agricultural Sciences and Spatial Planning (Formas) [Grant number 229-2013-82]. This work was funded by the Swedish Research Council for Environment.

\section{Compliance with ethical standards}

Conflict of interest The authors declare that they have no conflict of interest.

Open Access This article is distributed under the terms of the Creative Commons Attribution 4.0 International License (http:// creativecommons.org/licenses/by/4.0/), which permits unrestricted use, distribution, and reproduction in any medium, provided you give appropriate credit to the original author(s) and the source, provide a link to the Creative Commons license, and indicate if changes were made.

\section{References}

Ahlgren S, Hansson P-A, Kimming M, Aronsson P, Lundkvist H (2009) Greenhouse gas emissions from cultivation of agricultural crops for biofuels and production of biogas from manure-implementation of the Directive of the European Parliament and of the Council on the promotion of the use of energy from renewable sources. In: Revised according to instructions for interpretation of the Directive from the European Commission

Aoun WB, El-Akkari M, Gabrielle B, Flenet F (2014) Considering the variability of farming practices improves the LCA of biodiesel from oilseed rape. In: Proceedings of the 9th international conference on life cycle assessment in the agri-food sector. American Center for Life Cycle Assessment, San Francisco

Aronsson H, Torstensson G (2004) Beräkning av olika odlingsåtgärders inverkan på kväveutlakningen. Beskrivning av ett pedagogiskt verktyg för beräkning av kväveutlakning från enskilda fält och gårdar [Swedish]. Swedish University of Agricultural Sciences, Uppsala

Arvidsson J, Keller T (2011) Comparing penetrometer and shear vane measurements with measured and predicted mouldboard plough draught in a range of Swedish soils. Soil Tillage Res 111:219-223. https://doi.org/10.1016/j.still. 2010.10.005

Ashworth AJ, Taylor AM, Reed DL, Allen FL, Keyser PD, Tyler DD (2015) Environmental impact assessment of regional switchgrass feedstock production comparing nitrogen input scenarios and legume-intercropping systems. J Clean Prod 87:227-234. https://doi.org/10.1016/j. jclepro.2014.10.002

Balmford A et al (2018) The environmental costs and benefits of high-yield farming. Nat Sustain 1:477-485. https://doi.org/ 10.1038/s41893-018-0138-5

Bessou C, Lehuger S, Gabrielle B, Mary B (2013) Using a crop model to account for the effects of local factors on the LCA of sugar beet ethanol in Picardy region, France. Int J Life
Cycle Assess 18:24-36. https://doi.org/10.1007/s11367012-0457-0

Brander M, Sood A, Wylie C, Haughton A, Lovell J (2011) Electricity-specific emission factors for grid electricity. Econometrica. https://ecometrica.com/assets/Electricityspecific-emissionfactors-for-grid-electricity.pdf. Accessed 29 Oct 2018

Brankatschk G, Finkbeiner M (2014) Application of the Cereal Unit in a new allocation procedure for agricultural life cycle assessments. J Clean Prod 73:72-79. https://doi.org/ 10.1016/j.jclepro.2014.02.005

Brankatschk G, Finkbeiner M (2015) Modeling crop rotation in agricultural LCAs - challenges and potential solutions. Agric Syst 138:66-76. https://doi.org/10.1016/j.agsy.2015. 05.008

Brentrup F, Kusters J, Lammel J, Barraclough P, Kuhlmann H (2004) Environmental impact assessment of agricultural production systems using the life cycle assessment (LCA) methodology-II. The application to $\mathrm{N}$ fertilizer use in winter wheat production systems. Eur J Agron 20:265-279. https://doi.org/10.1016/s1161-0301(03)00039-x

Brentrup F, Hoxha A, Christensen B (2016) Carbon footprint analysis of mineral fertilizer production in Europe and other world regions. In: Paper presented at the LCA Food 2016, Dublin

Butterbach-Bahl K, Dannenmann M (2011) Denitrification and associated soil $\mathrm{N}_{2} \mathrm{O}$ emissions due to agricultural activities in a changing climate. Curr Opin Environ Sustain 3:389-395. https://doi.org/10.1016/j.cosust.2011.08.004

Caffrey KR, Veal MW (2013) Conducting an agricultural life cycle assessment: challenges and perspectives. Sci World J. https://doi.org/10.1155/2013/472431

Carlgren K, Mattsson L (2001) Swedish soil fertility experiments. Acta Agric Scand Sect B Soil Plant Sci 51:49-76. https://doi.org/10.1080/090647101753483787

Charles R, Jolliet O, Gaillard G, Pellet D (2006) Environmental analysis of intensity level in wheat crop production using life cycle assessment. Agric Ecosyst Environ 113:216-225. https://doi.org/10.1016/j.agee.2005.09.014

Cosme N, Hauschild MZ (2017) Characterization of waterborne nitrogen emissions for marine eutrophication modelling in life cycle impact assessment at the damage level and global scale. Int J Life Cycle Assess 22:1558-1570. https://doi. org/10.1007/s11367-017-1271-5

De Klein C, Novoa RSA, Ogle S, Smith KA, Rochette P, Wirth TC, McConkey BG, Mosier A, Rypdal K, Walsh M, Williams SA (2006) Chapter 11: $\mathrm{N}_{2} \mathrm{O}$ emissions from managed soils, and $\mathrm{CO}_{2}$ emissions from lime and urea application. In: Gytarsky M, Hiraishi T, Irving W, Krug T, Penman J (eds) 2006 IPCC guidelines for national greenhouse gas inventories. IPCC International Panel on Climate Change, Geneva, pp 11.1-11.54

Delin S, Stenberg M (2014) Effect of nitrogen fertilization on nitrate leaching in relation to grain yield response on loamy sand in Sweden. Eur J Agron 52:291-296. https://doi.org/ 10.1016/j.eja.2013.08.007

Delin S, Lindén B, Berglund K (2005) Yield and protein response to fertilizer nitrogen in different parts of a cereal field: potential of site-specific fertilization. Eur J Agron 22:325-336. https://doi.org/10.1016/j.eja.2004.05.001 
Diaz RJ, Rosenberg R (2008) Spreading dead zones and consequences for marine ecosystems. Science 321:926-929. https://doi.org/10.1126/science.1156401

Doltra J, Olesen JE (2013) The role of catch crops in the ecological intensification of spring cereals in organic farming under Nordic climate. Eur J Agron 44:98-108. https://doi. org/10.1016/j.eja.2012.03.006

Edström M, Pettersson O, Nilsson L, Hörndahl T (2005) Jordbrukssektorns energianvändning [Swedish]. Swedish Institute of Agricultural and Environmental Engineering (JTI), Uppsala

Eklöf P (2014) Marknadsöversikt - Spannmål. Jordbruksverket (Swedish Board of Agriculture)

EMEP/EEA (2016) EMEP/EEA air pollutant emission inventory guidebook 2016. In: Technical guidance to prepare national emission inventories, vol EEA report no 21/2016. European Environment Agency, Luxembourg

European Commission (2017) Modernising and simplifying the cap. In: Background document: climate and environmental challenges facing EU agriculture and rural areas. European Commission. Directorate-General for Agriculture and Rural Development, Brussels

FAO (2016) FAOSTAT statistics database: live animals, by 1058 country. http://www.fao.org/faostat/en/\#data/QA. Accessed 22 Feb 2019

Fertilizers Europe (2018a) Ammonium nitrate (AN, 33.5\% N); from ammonia and nitric acid, including primary production; production mix, at plant. UUID: c2c4ebba-358f-493e83ba-71bffe847e9a (version 00.00.001). thinkstep, GaBi database

Fertilizers Europe (2018b) Potassium chloride (KCl/MOP, 60\% $\mathrm{K}_{2} \mathrm{O}$ ); shaft mining and beneficiation, including primary production; production mix, at plant. UUID: a2a8695e968c-4341-922c-a007c8a8c56d (version: 00.00.001). thinkstep, GaBi database

Fertilizers Europe (2018c) Triple superphosphate (TSP, 46\% $\mathrm{P} 2 \mathrm{O5})$; rock phosphate acidulation with phosphoric acid, including primary production; production mix, at plant. UUID: 8d0007f0-9ad8-43b0-86e4-ebe6e9f9d0e6 (version 00.00.001). thinkstep, GaBi database

García-Ruiz R, Carranza-Gallego G, Aguilera E, De Molina MG, Guzmán GI (2019) C and N mineralisation of straw of traditional and modern wheat varieties in soils of contrasting fertility. Nutr Cycl Agroecosyst 113:167-179. https://doi.org/10.1007/s10705-019-09973-4

Gode J, Martinsson F, Hagberg L, Öman A, Höglund J, Palm D (2011) Miljöfaktaboken 2011. Estimated emission factors for fuels, electricity, heat and transport in sweden. Värmeforsk, Stockholm

Goglio P, Bonari E, Mazzoncini M (2012) LCA of cropping systems with different external input levels for energetic purposes. Biomass Bioenergy 42:33-42. https://doi.org/10. 1016/j.biombioe.2012.03.021

Goglio P, Grant BB, Smith WN, Desjardins RL, Worth DE, Zentner R, Malhi SS (2014) Impact of management strategies on the global warming potential at the cropping system level. Sci Total Environ 490:921-933. https://doi. org/10.1016/j.scitotenv.2014.05.070

Goglio P, Smith WN, Grant BB, Desjardins RL, McConkey BG, Campbell CA, Nemecek T (2015) Accounting for soil carbon changes in agricultural life cycle assessment
(LCA): a review. J Clean Prod 104:23-39. https://doi.org/ 10.1016/j.jclepro.2015.05.040

Goglio P et al (2018) A comparison of methods to quantify greenhouse gas emissions of cropping systems in LCA. J Clean Prod 172:4010-4017. https://doi.org/10.1016/j. jclepro.2017.03.133

Hammar T, Ericsson N, Sundberg C, Hansson PA (2014) Climate impact of willow grown for bioenergy in Sweden. Bioenergy Res 7:1529-1540. https://doi.org/10.1007/ s12155-014-9490-0

Henryson K, Hansson P-A, Sundberg C (2018) Spatially differentiated midpoint indicator for marine eutrophication of waterborne emissions in Sweden. Int J Life Cycle Assess 23:70-81. https://doi.org/10.1007/s11367-017-1298-7

Huttunen M, Vehviläinen B, Huttunen I (2013) Typen, fosforin ja kiintoaineksen pidättyminen vesistöissä-WSFS-Vemala-mallin arvio. Finnish Environment Institute, Helsinki

ISO (2006) ISO 14040: environmental management-life cycle assessment-principles and framework, 2. utg. edn. International Organization for Standardization (ISO), Geneva

Johnsson H, Mårtensson K, Lindsjö A, Persson K, Rangel YA, Blombäck K (2016) Läckage av näringsämnen från svensk åkermark. Beräkningar av normalläckage av kväve och fosfor för 2013 vol SMED Rapport Nr 189 2016. Sveriges Meteorologiska och Hydrologiska Institut, Norrköping

Kyllmar K, Carlsson C, Gustafson A, Ulen B, Johnsson H (2006) Nutrient discharge from small agricultural catchments in Sweden characterisation and trends. Agric Ecosyst Environ 115:15-26. https://doi.org/10.1016/j.agee. 2005.12.004

Lambin EF, Meyfroidt P (2011) Global land use change, economic globalization, and the looming land scarcity. Proc Natl Acad Sci 108:3465. https://doi.org/10.1073/pnas. 1100480108

Land M, Granéli W, Grimvall A, Hoffmann CC, Mitsch WJ, Tonderski KS, Verhoeven JTA (2016) How effective are created or restored freshwater wetlands for nitrogen and phosphorus removal? A systematic review. Environ Evid 5:9. https://doi.org/10.1186/s13750-016-0060-0

Licker R, Johnston M, Foley JA, Barford C, Kucharik CJ, Monfreda C, Ramankutty N (2010) Mind the gap: how do climate and agricultural management explain the 'yield gap' of croplands around the world? Glob Ecol Biogeogr 19:769-782. https://doi.org/10.1111/j.1466-8238.2010. 00563.x

Lindgren M, Pettersson O, Hansson P-A, Norén O (2002) Engine load pattern and engine exhaust gas emissions from off-road vehicles and methods to reduce fuel-consumption and engine exhaust gas emissions [Swedish]. Swedish Institute of Agricultural and Environmental Engineering (JTI), Uppsala

Myhre $G$ et al (2013) Anthropogenic and natural radiative forcing. In: Stocker TF, Qin D, Plattner G-K, Tignor M, Allen SK, Boschung J, Nauels A, Xia Y, Bex V, Midgley PM (eds) Climate change 2013: the physical science basis. Contribution of working group I to the fifth assessment report of the intergovernmental panel on climate change. Cambridge University Press, Cambridge

Nemecek T, Schnetzer J (2011a) Data collection of inputs and yields in LCIs of agricultural production systems in 
Switzerland and other European countries. Data v3.0. Agroscope, Zürich

Nemecek T, Schnetzer J (2011b) Data collection of inputs and yields in LCIs of agricultural seed production systems and seed processing-Data v3.0. Agroscope, Zürich

Nitschelm L et al (2017) Improving estimates of nitrogen emissions for life cycle assessment of cropping systems at the scale of an agricultural territory. Environ Sci Technol. https://doi.org/10.1021/acs.est.6b03865

Notarnicola B, Sala S, Anton A, McLaren SJ, Saouter E, Sonesson U (2017) The role of life cycle assessment in supporting sustainable agri-food systems: a review of the challenges. J Clean Prod Part 140(Part 2):399-409. https:// doi.org/10.1016/j.jclepro.2016.06.071

Page G, Ridoutt B, Bellotti B (2014) Location and technology options to reduce environmental impacts from agriculture. J Clean Prod 81:130-136. https://doi.org/10.1016/j.jclepro. 2014.06.055

Peter C, Fiore A, Hagemann U, Nendel C, Xiloyannis C (2016) Improving the accounting of field emissions in the carbon footprint of agricultural products: a comparison of default IPCC methods with readily available medium-effort modeling approaches. Int J Life Cycle Assess 21:791-805. https://doi.org/10.1007/s11367-016-1056-2

Potting J, Hauschild M (2006) Spatial differentiation in life cycle impact assessment: a decade of method development to increase the environmental realism of LCIA. Int J Life Cycle Assess 11:11-13. https://doi.org/10.1065/lca2006. 04.005

Prade T, Svensson SE, Björnsson L (2014) Introduction of grass-clover crops as biogas feedstock in cereal-dominated crop rotations. Part I: effects on soil organic carbon and food production. In: Schenck R, Huizenga D (eds) Proceedings of the 9th international conference on life cycle assessment in the agri-food sector (LCA Food 2014), 8-10 October 2014, San Francisco. ACLCA, Vashon, pp 1032-1041

Prechsl UE, Wittwer R, van der Heijden MGA, Lüscher G, Jeanneret P, Nemecek T (2017) Assessing the environmental impacts of cropping systems and cover crops: life cycle assessment of FAST, a long-term arable farming field experiment. Agric Syst 157:39-50. https://doi.org/10. 1016/j.agsy.2017.06.011

Rochette P et al (2018) Soil nitrous oxide emissions from agricultural soils in Canada: exploring relationships with soil, crop and climatic variables. Agric Ecosyst Environ 254:69-81. https://doi.org/10.1016/j.agee.2017.10.021

Ruan LL, Bhardwaj AK, Hamilton SK, Robertson GP (2016) Nitrogen fertilization challenges the climate benefit of cellulosic biofuels. Environ Res Lett 11:8. https://doi.org/ 10.1088/1748-9326/11/6/064007

Searchinger TD, Wirsenius S, Beringer T, Dumas P (2018) Assessing the efficiency of changes in land use for mitigating climate change. Nature 564:249-253. https://doi. org/10.1038/s41586-018-0757-z

Snyder CS, Bruulsema TW, Jensen TL, Fixen PE (2009) Review of greenhouse gas emissions from crop production systems and fertilizer management effects. Agric Ecosyst Environ 133:247-266. https://doi.org/10.1016/j.agee.2009.04.021

Statistics Sweden (2011) Växtskyddsmedel i jord-och trädgårdsbruket 2010. Användning i grödor. [Swedish]. Plant protection products in agriculture and horticulture. Use in crops. MI 31 SM 1101, Statistiska centralbyrån (SCB)

Statistics Sweden (2016) SCB statistikdatabasen: [Elektronic resource] Statistical database. Statistiska centralbyrån, Stockholm

Struijs J, Beusen A, van Jaarsveld H, Huijbregts MAJ (2013) Eutrophication. In: Goedkoop M, Heijungs R, Huijbregts M, De Schryver A, Struijs J, van Zelm R (eds) ReCiPe 2008. Report I: characterisation. First edition (version 1.08)

Sutton MA, Oenema O, Erisman JW, Leip A, van Grinsven H, Winiwarter W (2011) Too much of a good thing. Nature 472:159. https://doi.org/10.1038/472159a

Sutton MA et al (2013) Our nutrient world: the challenge to produce more food and energy with less pollution. Centre for Ecology and Hydrology, Edinburgh on behalf of the Global Partnership on Nutrient Management and the International Nitrogen Initiative

Swedish EPA (2006) Eutrophication of Swedish seas: final report. Report 5509. Swedish Environmental Protection Agency, Stockholm

Swedish Meteorological and Hydrological Institute (2018) SMHI Öppna data. Meteorologiska observationer. https:// opendata-download-metobs.smhi.se/explore/. Accessed 16 May 2018

Tilman D, Cassman KG, Matson PA, Naylor R, Polasky S (2002) Agricultural sustainability and intensive production practices. Nature 418:671-677. https://doi.org/10.1038/ nature 01014

Van Stappen F et al (2017) Sensitive parameters in local agricultural life cycle assessments: the illustrative case of cereal production in Wallonia, Belgium. Int J Life Cycle Assess. https://doi.org/10.1007/s11367-017-1325-8

Wang ZB, Zhang HL, Lu XH, Wang M, Chu QQ, Wen XY, Chen F (2016) Lowering carbon footprint of winter wheat by improving management practices in North China Plain. J Clean Prod 112:149-157. https://doi.org/10.1016/j. jclepro.2015.06.084

Williams AG, Audsley E, Sandars DL (2010) Environmental burdens of producing bread wheat, oilseed rape and potatoes in England and Wales using simulation and system modelling. Int J Life Cycle Assessment 15:855-868. https://doi.org/10.1007/s11367-010-0212-3

Zaher U, Stockle C, Painter K, Higgins S (2013) Life cycle assessment of the potential carbon credit from no- and reduced-tillage winter wheat-based cropping systems in Eastern Washington State. Agric Syst 122:73-78. https:// doi.org/10.1016/j.agsy.2013.08.004

Publisher's Note Springer Nature remains neutral with regard to jurisdictional claims in published maps and institutional affiliations. 